\title{
Best Practices for Implementing a Living Wage Policy in Canada: Using Community-Campus Partnerships to Further the Community's Goal
}

\author{
Natasha Pei, Janice Felthan, Ian Ford, Karen Schwartz
}

\begin{abstract}
The study explores one longitudinal case of engaged scholarship, the collaborative AвSTRACт "Best Practices for Implementing a Living Wage Policy in Canada: Using community-campus partnerships to further the community's goal" presents best practices for implementing a living wage policy, based on surveys and interviews of living wage advocates across Canada. This paper is a product of the ongoing partnership between Vibrant Communities Canada and Carleton University which is conducting a seven-year, SSHRC-funded study on how community-campus relationships can use joint resources to create practice and policy changes in the battle against poverty. For eight months, a group of Master of Social Work students researched the status of the working poor and the progress of living wage campaigns in North America, and analyzed data collected through surveys and interviews with individuals engaged in living wage campaigns. Recommendations for best practices to implement a living wage policy are discussed and include (a) developing a core group of individuals, (b) engaging champions to extend the buy-in of companies, (c) establishing a positive framework for the campaign, and (d) dedicating more resources to research and knowledge. This work is intended to facilitate discussion and create real impact on minimum wage regulations and business practices, resulting in increased social inclusion for individuals who identify as living in poverty.
\end{abstract}

KEYWORDS living wage, collective impact, engaged scholarship, vibrant communities

\section{Introduction}

Among many innovative approaches to reduce poverty in Canada, Communities First: Impacts of Community Engagement (CFICE) is spearheading an exploratory investigation on using community-campus partnerships to create policy and practice change. The project that this paper will report on operated on three levels simultaneously. ${ }^{1}$ On a macro level, the

\footnotetext{
${ }^{1}$ This project has received Carleton University Research Ethics Board approval for the period of December 4, 2013 - May 31, 2014
} 
federally funded (Social Sciences and Humanities Research Council- SSHRC) CFICE project designated one hub of this projectforpairinganacademic facultymemberwithacommunity organization (Vibrant Communities-a Pan-Canadian network of anti-poverty groups) to engage in demonstration projects that would illuminate the benefits of community engagement with a university. On a mezzo level, the research course was guided by the Poverty Reduction Hub's academic and community co-leads and taught by a third-party academic member. This community-based research course pairs students with community organizations to engage in research that the organization has identified as a need, but does not have the

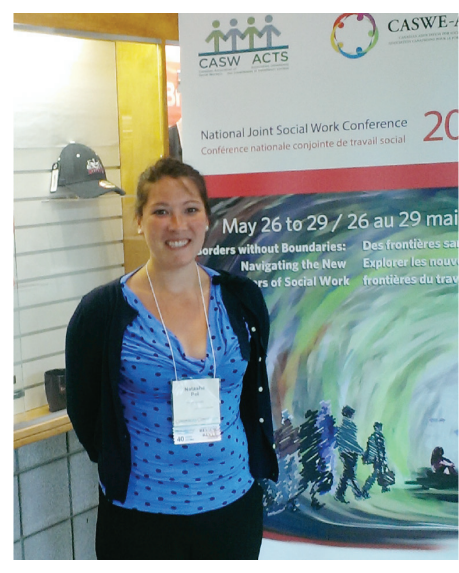
capacity to carry out. For course credit, students were engaged in a project that was an offshoot of one of the CFICE projects, exploring best practices for implementing a living wage. On a micro level, students engaged in an actual research project and identified important strategies to encourage employers to implement a living wage.

It is always a challenge to find adequate funds to do community-engaged research, and often these projects operate at such a high level of complexity to garner enough resources to collect the evidence needed to have an impact upon policy development. Since literature already exists on community-engaged research (Hall \& Keller, 2006; Seifer, 2006; Flicker, 2008) and community-engaged research is being incorporated into coursework (Hyde \& Meyer, 2004; Hayes, 2006; Schwartz, 2010; van de Sande \& Schwartz, 2011), this article is focused on the research that contributes to policy change in keeping with the spirit of the CFICE project.

At the macro level, Communities First: Impacts of Community Engagement (CFICE) has engaged faculty members and community partners across Canada in exploring whether community-campus partnerships benefit the community. CFICE has created five thematic hubs, including the Poverty Reduction Hub, established to maximize the synergy created from community-based organizations and university partnerships, with the mandate of using these synergies to reduce poverty across Canadian municipalities. Vibrant Communities, a backbone of Canada's national poverty activism and the living wage movement, contracted MSW students to carry out a descriptive study of the experiences of living wage advocates around the country and suggest best practices for convincing businesses to implement the living wage policy to strengthen the organization's living wage campaign, increase utilization of university resources (i.e. students), and create community awareness of issues.

At the mezzo level, the research course that enabled the students' participation in the project is a full-year course structured to enable small groups of students to engage in research with community agencies. Each July community organizations are invited by letter to submit a request for research. The submitted proposals are situated at various points along the continuum of community-campus research as described by McDonald (2007). The community partner in the case under consideration here, Vibrant Communities, acted as a consultation group, allowing students considerable liberty in designing the research protocol and carrying out the 
research. The students conduct the research while simultaneously learning about communitybased research methods.

Providing a living wage is one of many recommended methods for combating poverty for which Vibrant Communities and other community-based organizations have advocated. The Canadian Centre for Policy Alternatives (CCPA) conceptualizes it as "a wage that allows working people not just to survive (in minimal physiological terms) but to enjoy a decent quality of life in which one can raise a family, be healthy and enjoy recreation, culture, entertainment and participate fully in social life" (Mackenzie and Stanford, 2008, pg.7). In other words, a living wage provides enough income to ensure full social inclusion for healthy families and individuals. In contrast, social exclusion is identified by the CCPA as principally income exclusion, but also includes other dimensions of community life exclusion, such as "health, education, access to services, housing, debt, quality of life, dignity and autonomy; [social exclusion] is deeply rooted and relational" (Mackinnon, 2008).

The living wage calculation varies across time, place, and employer. It is affected by the cost of necessities required for social inclusion (e.g. internet access, cell phones), by financial and service supports provided by governments, and by any benefits individual employers already provide. Groups across Canada and around the world have lobbied for living wage programs, some with great success. This paper will present a brief overview of the experience of living wage advocates in Canada and make

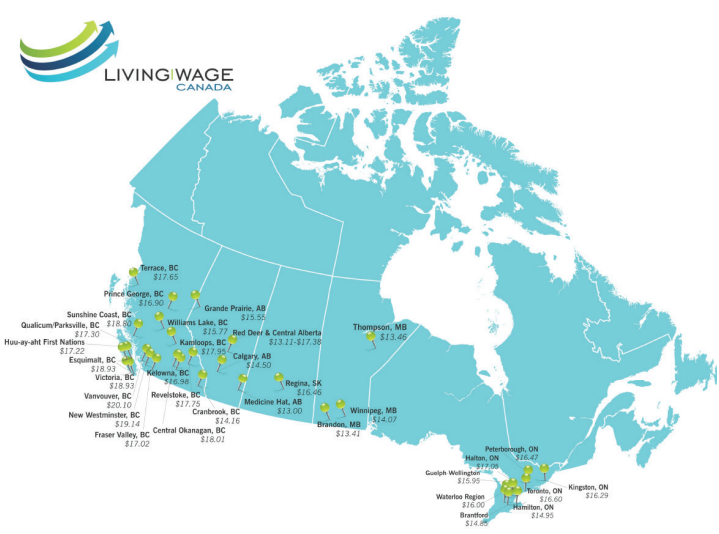
recommendations on best practices for implementation. The goal of these best practices is to connect patterns and success stories that will assist other advocates to effectively convey the message of the need for a living wage to business owners and employers.

\section{Literature Review}

In reviewing the literature pertaining to the living wage implementation and advocacy in North America, it is important to recognize that the proposed change in wages has implications for numerous members of society: people who have a low income and experience poverty, and businesses that provide living wages. The Literature Review begins with a definition of living wage, including its benefits and limitations, considers barriers living wage advocates face in implementing the living wage, reviews living wage campaign methodology of successful regions, and describes benefits realized by living wage employers.

\section{Definition of Living Wage}

While there are technical calculations that constitute the definition of a living wage, the point of such a definition is to ensure that children grow up to lead more fulfilling and successful 
lives. The Canadian Centre for Policy Alternatives (CCPA) has recently released a standardized definition and calculation guide for living wage advocacy groups to use across the country. The most recent version, which serves as the basis for calculation in twenty-five communities across Canada (Ivanova \& Klein, 2013), states:

The living wage is calculated as the hourly rate at which a household can meet its basic needs, once government transfers have been added to the family's income (such as the Universal Child Care Benefit) and deductions have been subtracted (such as income taxes and Employment Insurance premiums). (Ivanova \& Klein, 2013, p. 2)

Another Canadian definition states, "a living wage is based on basic working conditions, seventy hours of work per week between two people, and already incorporates government transfers (e.g. the Canadian Child Tax Benefit) and deductions (e.g. taxes, E.I. and CPP premiums)" (McCarthy Flynn, 2012, p. 13).

There are numerous limitations to these kinds of calculations. These calculations rely on a limited household budget that does not consider minimally expected entertainment, inflation, increased transportation costs, food, and child care (Ivanova \& Klein, 2013). The calculation subtracts government transfers such as childcare, and does not provide room for payments of any family debt (Graces, 2011). While some may challenge the assumption that a living wage is an effective means to address a broad range of social issues such as child poverty, health coverage, and housing, the authors argue that it is the government's duty to increase transfers to families, such as higher childcare subsidies, and the private sector's responsibility to provide a living wage (Ivanova \& Klein, 2013).

One barrier to the implementation of the living wage is that employers are not legally obligated to provide a living wage, although they are obligated to pay minimum wages (Graces, 2011). Presumably, employers must be convinced to provide a living wage through advocacy and a demonstration of its potential benefits.

The main beneficiaries of a living wage will be primarily individuals and families with low incomes, who will enjoy an increased quality of life (Graces, 2011). Outcomes of a living wage for employers include Corporate Social Responsibility (CSR) benefits, showcasing a more humane, positive brand. Such a wage has also been predicted to increase productivity and decrease employee absenteeism and turnover rates (Graces, 2011) (Brenner, 2005).

There is also a compelling argument to be made for a living wage as a human rights issue. Cornish (2012) makes the case for implementing a living wage to counter the effects of historical discriminatory practices, including pay gaps, among governments and employers. Low wages can be viewed as bad public policy, and bad pay leads to negative health and social outcomes (Cornish, 2012). Historically, women and people who face racism make significantly less money than those who have not been marginalized (Cornish, 2012). Additionally, a country that does not implement a living wage will not be able to compete in a global economy because low wages devalue the skill of vulnerable workers, especially during a time when the economy

Engaged Scholar Journal: Community-Engaged Research, Teaching and Learning 
requires highly skilled workers (Cornish, 2012).

\section{Implementation of Living Wage}

The literature and primary research on the living wage is largely American-centric, and while our cultural and socioeconomic systems are comparable and living wage advocates have borrowed lessons and theories from living wage success stories, the approach of American and Canadian living wage advocates and their outcomes have been somewhat different. American living wage advocates have focused predominantly on legislating a living wage through city ordinances. In 1994, Baltimore became the first city to adopt a living wage before being followed by 200 more communities (Brooks, 2007). Brooks (2007) highlights how Baltimore's increasingly privatized economic system in the 1990s created a shift in the labour market towards poor quality jobs, and a noticeable increase in the number of paid employees accessing charitable and social services. Stevenson (2010) builds on this, arguing that as the social and economic climate frustrated clientele across several service sector providers, it united the goals of faithbased groups, unions, and community organizations. Stevenson (2010) and Niedt et al (1999) both describe the campaign being led by a single organization, forging an economic case for the redirection of public finances; advocates argued for the community as a whole to benefit from livable wages, rather than government spending on social programs for the poor. Using Baltimore as a case study, Stevenson (2010) claims that the energy driving the living wage is the recognition that full-time employment no longer ensures a decent standard of living, and implies that the current competitive economic climate set the conditions which create the working poor.

Strikingly similar to the Baltimore case, Brenner and Luce (2005) add to the post-living wage body of information with their research on the Boston, Massachusetts, experience. As in Baltimore, privatization and low-wage, low-benefit jobs spurred multi-sectoral living wage advocates into forming a collective in Boston, successfully influencing a living wage ordinance.

In contrast to the American experience, Canada has been slower to adopt living wage practices, and Canadian living wage advocates have opted to focus more on bringing municipal representatives into their cross-collaborative living wage campaigns, instead of lobbying businesses to voluntarily adopt the wage. Yet our economies are relatively similar and greatly intertwined; Canadians tend to look south of the border for relevant theories, comparable experiences, and lessons learned. For instance, the Simon Fraser Institute opposes the living wage in Canada based on data and analyses being published out of the States (Lamman 2014). Moreover, as the living wage is still a relatively new practice, living wage advocates are left to arm themselves with American studies to make their case.

As of January 2014, the City of New Westminster, B.C. is the only Canadian city with a living wage ordinance (Lamman, 2014, pg.1). However, Michael McCarthy-Flynn's 2012 report gives an overview of Simon Fraser University's (SFU) decision to become the first living wage employer in Canada in 2013; the decision was influenced by an internal collaborative table of student groups, unions, and social justice organizations who appealed to the university in business terms, framing their argument around Corporate Social Responsibility (CSR). These 
advocates raised questions about the university's failure to provide a healthy and sustainable quality of life to their low-waged auxiliary workers, contrary to the university's vision and public image, and presented an opportunity to the university to act as a leader in its sector (McCarthy Flynn, 2012).

The research by McCarthy Flynn (2012) on SFU's implementation focuses on exploring the multi-dimensional impact of living wage policies on individuals and families as well as implications for the university as a living wage employer. Benefits to employers who adopt living wage policies are described as follows:

i) Decreased employee turnover; cost savings for staff hiring and training; lower absenteeism, ii) Improved job quality, productivity and service delivery, iii) Benefits the broader economy by stimulating consumer spending, and iv) Greater corporate social responsibility and organization reputation. (McCarthy Flynn, 2012, pp. 30-31).

\section{Engaging Stakeholders}

Advocates for a living wage often make the argument that engaging the business community and employers is necessary. Robert White (2012) states that antipoverty groups and stakeholders must engage and collaborate with employers. White explains that the benefits to the employees and employer are reduced stress for employees and increased productivity (2012). In addition, White (2012) argues that the CSR model, which proposes that implementation of a living wage is socially responsible, is a benefit to employers that has not been adequately utilized. Loewen (2008) outlines pillars for social groups to frame their business partnerships, and to engage the private sector. He uses case studies to convince the reader of the benefits of involving businesses in advocacy work, identifies challenges, and offers methods to overcome them, and tools for engaging business partnerships (pp.5-6).

\section{Gaps in the Literature}

Most of the literature on living wage focuses on how a living wage is calculated and where it has been implemented. One gap is a business and economic-centric compilation of data, which focuses on understanding how the living wage will affect business owners and employers. There is a lack of literature on the role that social justice organizations play in the implementation and the realized outcomes for the working poor and communities that have experienced wage increases. This research will attempt to address the former of these gaps, as the group intends to focus on practice strategies for living wage advocates. Further, the implementation of the living wage policy has focused on the United States. This research will provide a useful description of the Canadian context; in the long-term, it is hoped that this will enhance the probability that Canadian businesses will adopt the living wage policy.

\section{Methodology}

In the Social Work Research Methods course (September 2013- April 2014), students were able to select their research projects in the first two weeks depending on the project title and community

Engaged Scholar Journal: Community-Engaged Research, Teaching and Learning 
partner. The research planning commenced immediately, and occurred simultaneously with weekly course lectures on best practices for community-based research. Students were instructed on how to prepare an ethics proposal, reminded of the importance of including all stakeholders in the research, and assigned to prepare their proposals during the first semester. The community partner provided recommendations and supervision throughout the research project.

This research project was reviewed by the Carleton University Research Ethics Board and received approval effective December 4, 2013 until May 31, 2014.

\section{Sampling Procedures}

Quantitative data was collected using a purposive sample that met the inclusion criteria of being living wage advocates across Canada who were connected to Vibrant Communities Canada. They were invited to participate by clicking on the FluidSurvey link in the invitations they received through email and/or via Vibrant Communities Canada's Twitter feed. Members of the research team also encouraged participation at Tamarack's monthly living wage community of practice teleconference.

The qualitative data was collected upon completion of the survey phase of the project. A convenient sample of living wage advocates was identified with the help of the Advisory Committee. ${ }^{2}$ The research team contacted seven potential interview participants by e-mail, inviting them to participate in an interview as a means to obtain information related to their experience regarding living wage advocacy. Potential interviewees were drawn from across the country and from communities of varying population size.

\section{Data Collection Method/Instrument}

Quantitative data was collected first through an on-line survey designed by the research team in consultation with the Advisory Committee and hosted by FluidSurvey. The survey, available for seven weeks, invited participants to share their living wage advocacy experiences by responding to a diverse range of questions. The survey, consisting of fifty questions, included:

- non-identifiable demographic data (i.e. province of residence, population of city, participant's role in their community organization and years with the community organization),

- community organization participation,

- living wage calculation,

- information related to potential/actual living wage employers,

- strategies and data used when advocating for a living wage,

- experiences in living wage advocacy including barriers, and

- perceived benefits of a living wage.

\footnotetext{
${ }^{2}$ Our Advisory Committee consisted of academic and community partners engaged in poverty reduction work, and who provided support, input and feedback throughout the research project.
} 
Participants were informed of their right to exit from the survey at any point prior to the selection of the "submit" button at the end of the survey. Un-submitted survey data was not included in the data collection and analysis; however, due to participant anonymity, responses could not be withdrawn from the compiled data once surveys had been submitted.

The qualitative data collection consisted of 30 - 45 minute semi-structured interviews with living wage advocates representing diverse geographic locations and population sizes. Although the interview included demographic information and information relating to a living wage definition, the primary focus of the discussion regarded the interviewee's advocacy experience. Participants were known to the research team; however, identifiable information is not included in this article. With the express consent of the interviewees, the interviews were audio-recorded. Interview notes were then reviewed by the participants to ensure that all responses were accurately represented.

\section{Analysis}

This research project is descriptive in nature, with the intention to provide the readers with a picture of the experiences and approaches used by living wage advocates. The survey data was analyzed using SPSS software, providing the researchers with the ability to assess the presence of trends, experiences of, and outcomes obtained by living wage advocates through the use of frequencies and measures of central tendencies.

A qualitative data analysis was performed using the data obtained during the interview phase of the project. At least two research team members conducted each interview with one taking responsibility for transcribing the interview. To ensure that the analysis could be confirmed, the research team used the triangulation method as each of the three members independently reviewed data to identify themes for approaching businesses. The research team then discussed and further organized the original themes into four broad themes and related subthemes, and compared and incorporated relevant quantitative data to create recommendations for advocates.

\section{Quantitative Data Results}

\section{Demographics}

The questionnaire was available to living wage advocates across the country. Thirty-six individuals accessed the survey, of which ten completed the survey. For reasons that have not yet been analyzed, the respondents resided either in Ontario or British Columbia, representing centres ranging from a population of 8,000 - 3,000,000 (mode population of 100,000 199,$999 ; \mathrm{n}=4$ ). Respondents represented a range of experience based on years involved in their organization $(.5-15$ years; mean $=5$ years; median $=3.5$ years) and roles (coordinator, community developer, executive director, chair, founder, member, public health nurse, research and policy analyst, social planner).

The majority of survey participants $(n=9)$ identified partnering with other organizations in their living wage campaign group. The number of partner organizations ranged from 1 to 
$15+$ partners (with one participant describing "lots" of partner organizations). Within the living wage campaigns, participant responses indicated diversity in the number of individual advocates involved, ranging from 1 to 200 advocates per campaign group (the approximate mean number of advocates per campaign is 40.4, with the median being 15). When asked to identify their biggest allies in the community, the survey participants noted "other advocacy groups" ( $\mathrm{n}=4)$, “unions” ( $\mathrm{n}=3)$, "Living Wage campaign groups in other cities" $(\mathrm{n}=2)$ and "unskilled labourers" ( $\mathrm{n}=1)$.

When asked to describe their campaign's progress in their community, five participants indicated that the living wage had been or was in the process of being calculated, three indicated that they were approaching employers/governments, and three indicated that they were certifying living wage employers.

\section{Experience with Living Wage Employers}

Whom to Approach? Surveyed living wage advocates are in contact with a wide variety of populations and organizations. Through their living wage campaigns, survey participants are most frequently in contact with municipal government $(\mathrm{n}=8)$, community organizations ( $\mathrm{n}$ $=8$ ) and small to medium businesses $(n=7)$. It is noted that these same sectors were perceived to be the most receptive to the living wage (with seven participants identifying community organizations and five identifying municipal government and small-to-medium businesses as most receptive), and, in two cases, are further considered to be the main targets of participants' living wage campaigns (communities and businesses representing 30\% of responses each). Neither federal nor provincial governments were identified by survey participants as being receptive to the living wage.

When approaching an organization, $50 \%$ of survey participants identified management as being their point of entry, with a personal contact being the most frequent first approach ( $\mathrm{n}=$ 6). However, front-line staff $(30 \%)$ and individuals in human resources $(20 \%)$ were found to be more responsive toward the living wage than management, directors/chief officer(s) and volunteers - each representing 10\% of responses-while no one identified members of the board, CSR teams or elected representatives as being the most responsive.

Survey participants have approached anywhere from 0 to $20+$ employers, with $50 \%$ approaching two to four employers at the time of the survey $(20 \%$ have approached $0-1$ while $20 \%$ have approached 5 - 10 employers). Out of those approached, the greatest number of survey participants indicated that $1-15 \%$ of employers have been "receptive" to the living wage $(n=3)$, with $20 \%$ indicating 15 - 30\% have been "receptive." Although half of the participants indicated that $0 \%$ of approached businesses have "adopted" a living wage, four indicated that $1-30 \%$ have done so, while one participant indicated that $45-60 \%$ have adopted a living wage. Additionally, two participants each indicated that $1-15 \%$ and $30-45 \%$ are in the process of adopting a living wage while one indicated that $90-100 \%$ of approached employers are in the process of adopting it. Businesses that chose to move forward with the living wage were noted by survey participants to share some common characteristics which include being non-profit/voluntary organizations $(n=4)$ and/or organizations with a 
sympathetic manager/employer $(\mathrm{n}=4)$.

How to Frame the Argument? Survey participants were provided with a list of eleven potential reasons describing why businesses may choose to implement a living wage. Participants were asked to rate each potential reason, based on their experience, as "very important," "somewhat important," or "not important." The top five "very important" reasons for businesses choosing to implement a living wage are sympathetic employer/personal characteristics ( $\mathrm{n}=$ $5)$, improved ability to recruit and/or retain employees $(n=4)$, worker/union pressure $(n=$ 4), community pressure $(n=3)$, and care for employees $(n=3)$.

The most frequently perceived reason for business refusal of the living wage was that the wage is considered "too expensive" $(n=3)$. Additional perceived reasons for business refusal of the living wage include (a) no one else is doing it, (b) not enough benefit returns promised to the company, (c) worry about union/wage demands increasing, (d) not wanting to overpay unskilled workers and (e) fundamental perspective differences ( $\mathrm{n}=1$ for each additional reason).

After initially being approached by a living wage advocate, survey participants responded that the business' first reaction is to (a) ask for more information about the living wage $(n=2)$, (b) debate the living wage in terms of economics and the effects of increasing the minimum wage ( $\mathrm{n}=2)$, (c) ask for a more detailed list of benefits to the company ( $\mathrm{n}=1)$ and $(\mathrm{d})$ ask for a written proposal $(n=1)$.

Which Data to Use and Present? Government data (i.e. data from Statistics Canada, Health Canada, etc.) is one of the main data source used by $90 \%$ of survey participants, with data from socially-progressive think tanks and published organizational data also noted $(\mathrm{n}=6$ each). Other main data sources include scholarly articles/peer reviewed journals $(n=4)$ and personal internet-based research $(n=4)$.

Survey participants were asked what type of data, in their experience, generally leads more readily to actual living wage implementation, data that appeals to knowledge such as empirical data or data that appeals to emotion such as case studies/ideological arguments/images. $70 \%$ of participants selected data that appeals to knowledge while 30\% selected data that appeals to emotion. This data most often lists benefits to society and workers $(n=8)$; benefits to the company ( $\mathrm{n}=7$ ); economic problems of the current system for society $(\mathrm{n}=7)$; and economic problems of the current system for workers/economic problems with Living Wage (to address/refute) $(\mathrm{n}=4)$ (five participants identified the use of case studies/examples from other regions, four participants present local case studies/examples, and none of the survey participants indicated that they present data such as leadership promises to the company and cost/balance projections for the company's bottom-line).

Participants classified fourteen types of data as (a) very useful to have, (b) somewhat useful to have, (c) not useful, or (d) data which they already have. It was noted, by the greatest frequencies of responses, that a range of empirical data would be very useful to the survey participants. Table 1 represents data most frequently determined to be "very useful" by survey participants. 


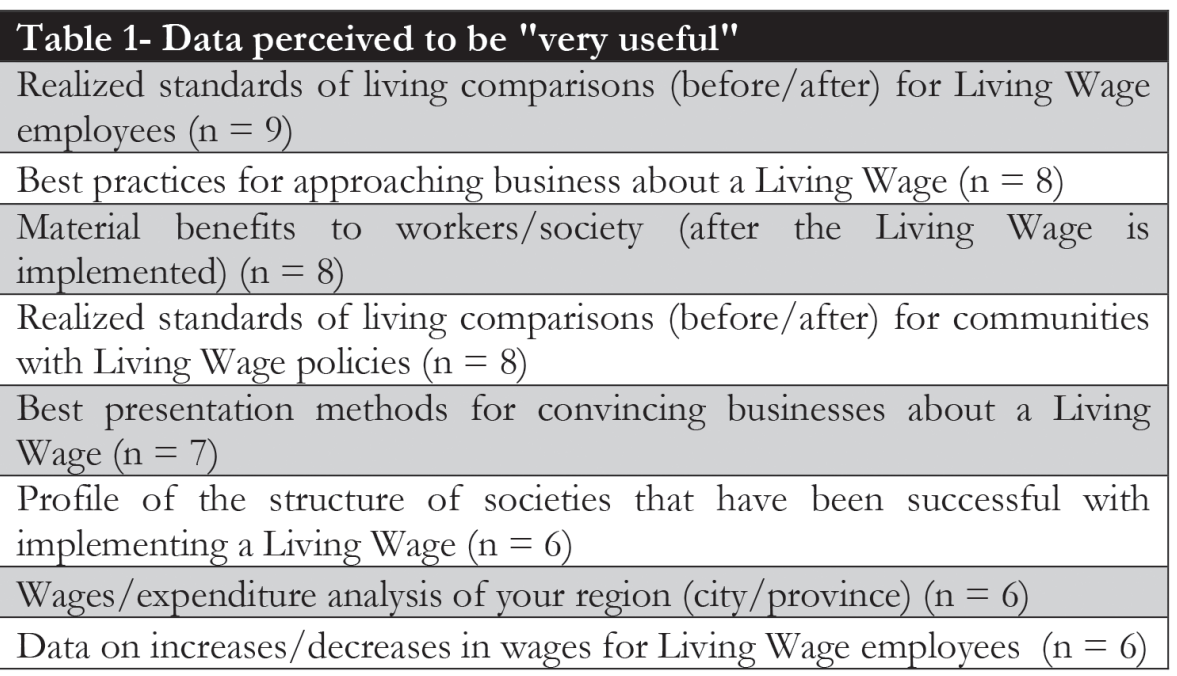

\section{Barriers to Living Wage Implementation}

Survey participants were provided with a list of twenty-seven potential barriers that they might encounter during their advocacy efforts regarding the implementation of a living wage. For each barrier, participants were asked to rate it as (a) a large barrier, (b) a small barrier or (c) not an issue. The top five "large" barriers were lack of human resources, lack of supportive data, inability to reach top company decision makers, lack of interest of government and policy makers, and lack of interest of companies (all $n=5)$. When asked what they considered to be the biggest barrier keeping companies from implementing a living wage, participants most frequently noted a lack of community support (including municipal government) and lack of funds ( $\mathrm{n}=2$ for each reason).

\section{Qualitative Data Analysis}

The research team conducted 20 - 45 minute telephone/Skype phone interviews with four living wage advocates representing living wage campaigns in British Columbia, Alberta and Ontario. Interview participants represent diversity with respect to regional representation, role within their living wage campaign, and gender. Additionally, the four interviewees represent living wage campaigns at various stages of development and activity, as identified by the participants themselves. For example, one participant identified their campaign as being "more mature compared to other living wage campaigns in" their region (i.e. calculated the living wage, engaged employers, had a few champions sign-on) while another participant noted that they are at the beginning stage (i.e. have established a core group yet haven't moved forward into certifying living wage employers). It is important to note that, due to the small sample size, the scope of the analysis was limited and results cannot be generalized. However, this analysis does provide a snapshot of the ideas, insights and experiences of living wage advocates in two broad themes. 


\section{Importance of Networks}

"we think it's important that if we are approaching a business in another municipality, that it's somebody from that municipality that approaches the employer, rather than us coming in from another saying we suggest you do this."

Networks are important to interviewees, are not limited by geographic location, and may comprise connections across the country. For example, it was noted by one interviewee that communities of practice ("small, interactive groups of practitioners who meet by telephone and online to learn and share their experiences" 3 ), such as the "living wage community of practice" facilitated by Tamarack, provide opportunities for individuals to connect with others involved in similar campaigns. Additionally, work done by other communities was seen as a resource, especially in the beginning phases of a campaign, and facilitated the progress of living wage implementation. One interviewee noted that he/she would "encourage other groups to get involved in the living wage community of practice and participate in that for the experiences of other communities."

The interviewees discussed the practice of starting with a "core group" of individuals and organizations to create the foundation of the campaign and drive it forward. Interviews revealed that these core individuals and organizations had been largely from the community/ non-profit sector, but advocates saw the importance of including representation from other sectors. Two individuals identified the core group as a major strength because of the "conviction" or "passion" they have for the benefits of a living wage on the community. Two of four interviewees stated that respondents come to the table with their own contacts and expertise, and could create more networking throughout the community. In fact, another two of four participants regarded personal contacts as their main form of first approach to other businesses/organizations, and one considered networking as a primary campaign activity.

Having a diversity of membership within the living wage campaign and collaboration with allies was also seen as important; this diversity includes skills, resources, connections and expertise/knowledge. One interviewee recognized the diverse skills and experience already within their core group, commenting that some organizations do fundraising and know how to talk to businesses and have contacts established already through that network. Another identified financial contribution, time and energy support from core individuals and organizations as key strengths of the campaign. There was an overall effort to have a core group of organizations to support and lend credit to the campaign. As well, one mentioned the value of partnering with the local business school, and its ability to lend credibility to the campaign where he/she felt they lacked credentials, as such a business school already has respect from the private sector in the community. Having an overall diversity of sectors was

\footnotetext{
${ }^{3}$ As described online at Tamarack Institute's website: http://tamarackcommunity.ca/events.html
} 
also important to participants. Each campaign had already initiated or had plans to include various combinations of government, businesses, non-profit (including post-secondary and secondary schools) and communities (including faith groups, labour unions, etc.).

Overall, collaborating and creating allies and partners within the community was an important aspect of the living wage campaigns. Along with various individuals committed to the living wage campaign, participants saw a benefit in allying with other progressive organizations, such as the local Chamber of Commerce or environmental organizations. As well, when prompted about union participation, three of four participants said that they have contacted unions or had a union member in their group, though one cautioned about difficult conversations with union leaders and members because of pay grids.

\section{Campaign Approach}

"...we really want to work on showing them what the value of this is for employees and for communities as a whole."

How the participants approached their campaign was found to be very positive. The participants were all very knowledgeable and understood the need for having a living wage - data and knowledge were seen as an important aspect of their campaigns. Furthermore, the importance of not having a fear-driven campaign was noted. A pattern evident in each interview was the lack of negative language and the positive campaign

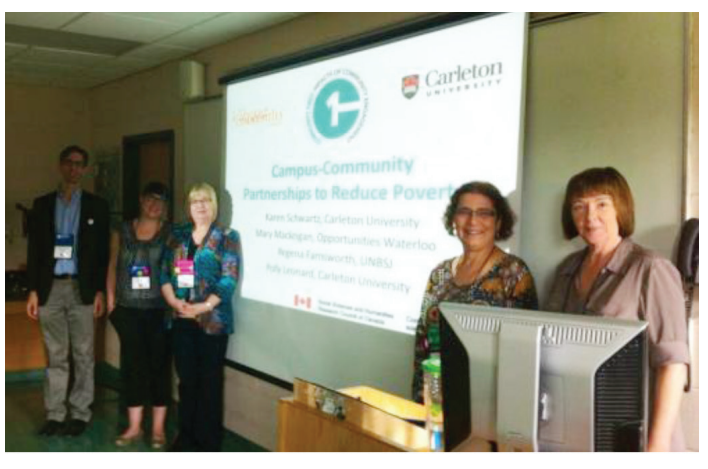
outlook held by the interviewees, especially in their discussion of private enterprise engagement. Only one interviewee reported using a message of compassion; it was more common to perceive participants expressing the desire for positive data to buttress their campaigns, such as successful case studies on the living wage. One participant mentioned a lack of diversity within the living wage campaign group that would have allowed people to challenge each other, and another mentioned that financial resources were limited, making human resources also limited.

Knowledge was highly prized by four of four interviewees, especially information obtained from other living wage advocates or campaigns. Some interviewees acknowledged informing their activities by looking at living wage campaigns in other regions, and/or using the Canadian Centre for Policy Alternatives and Vibrant Communities for technical support and background information. One interviewee was very adamant that their core group should first build a solid base of knowledge and become informed before launching their campaign because he/she recognized that it was a very new concept for them. Three participants recommended studying or getting involved with other campaigns first to inform their own; other campaign models, background 
information, arguments and strategies were mentioned by interviewees as being useful.

Three of four participants talked about the importance of awareness and/or the need to engage the community in conversation about the living wage, and all four saw the importance of using media to facilitate this visibility in the community. Media was mentioned multiple times with respect to creating awareness and knowledge of the living wage, sparking conversations or capitalizing on similar ones that are already happening. One interviewee mentioned that the current climate is conducive to having this discussion with employers. Multiple interviewees also reported using the initial hype of the campaign launch or wage calculation to keep the living wage continually in the forefront of conversation. Methods used include online social media (blogs, Twitter, Facebook, websites) or local media outlets such as news organizations.

Another strategy that participants used in their approach to campaigning was the use of "champions" and living wage "leaders." Mentioned in three of four interviews, champions/ leaders are not only employers who have adopted the living wage, but who lead by example to actively promote the living wage policy. Champions were seen to encourage others, and speak the specific language of businesses and governments. Interviewees mentioned their strategy to gain one or two of these champions in diverse sectors to help navigate among the different values of the sectors and to speak the same language.

\section{Recommendations for Facilitating a Living Wage Campaign}

Drawing on complimentary data from interview themes and survey frequencies, the following best practice recommendations have been prepared for living wage advocates, researchers, and interested parties:

\section{Develop a Dedicated Group of Core Individuals and Organizations that have Diverse Skills and Contacts}

The survey data shows that the majority of groups have one to sixteen advocates in their living wage working group, (range of 6-15 "core" individuals). Interviewees identified this group of advocates as one of the main strengths of their campaign. These advocates are truly dedicated and believe that a living wage policy would positively impact the community. These core individuals are often associated with organizations that also support the living wage campaign, donating their diverse skills, knowledge and contacts. Diversity in the campaign group is seen as being a great asset because it brings new voices to a group of often like-minded people. Most advocates ranked "other advocacy groups" as their biggest allies, followed closely by "unions," "living wage campaign groups in other cities," and "unskilled labourers." The use of individual and organizational contacts is also seen as important for the initial introduction of the living wage, with $60 \%$ of survey responses indicating personal contacts are their main method of approaching businesses or organizations, and 60\% saying management is generally their main point of entry. Among other methods, participants identified networking as a good strategy to spread the word about the living wage.

Engaged Scholar Journal: Community-Engaged Research, Teaching and Learning 


\section{Engage a Couple of Champions to Help Extend the Range of Buy-in by more Companies and Organizations}

It is important to find one or two members in the business sector to become living wage employers, who can then get more companies involved. Champions in the business (or other) sectors can lend credibility to the living wage debate and can assist by speaking the same language; they understand the other party's values when trying to persuade them of the living wage's viability. The importance of employers buying-in and appreciating the "value . . . for employees and the community as a whole ... . how it creates a better quality of life and [a] better product. . .”, rather than being shamed into offering the wage was addressed by one interviewee. As well, a couple of interviewees felt they lacked business credentials in the community, making it harder to be taken seriously; however, with the partnership of a well-known for-profit organization, they have been able to appeal to other businesses more effectively. To find these champions, suggestions include starting with small CSRminded businesses, businesses who are already close to being living wage employers (i.e. living wage would be the next logical step) and/or those who have a progressive mentality (e.g. environmental organizations). Survey data supporting this indicates that community organizations, small to medium local businesses and municipal governments have been more responsive to the living wage case than large companies (national/international).

\section{A Positive Framework for the Campaign}

A common trend in both the survey data and interviews is the construction of an overall positive framework for the campaign, rather than a deficit-framed or fear-inspiring campaign (e.g. messages evoking sympathy, deficits in society, shaming or blaming approach, etc.). Three interviewees use a positive values-based approach, and survey respondents also indicated that benefits to society, benefits to workers, and benefits to companies were among the most presented types of information. Further, participants generally indicated that successful living wage cases, realized standards of living for workers and the community-before and after the living wage — and material benefits to society and workers would be the most useful information. When asked, three of four interviewees identified businesses not as "barriers" "harder to penetrate." One interviewee stated,

each sector will have those who are a little more on board than others and a little more accepting of the information .... I think the business sector is a little more than others, but there are still people who are interested in it. I think each sector has people who are a little more on one side versus the other.

As well, $40 \%$ of surveyed individuals indicated they do use a hook or promise to appeal to businesses, with most offering "awards and other recognition events for employers" or "reduce[d] cost to society," and when met by employer concern about market effects of the 
living wage, more campaigners used successful case studies as their counterarguments. It was mentioned numerous times by interviewees that encouraging, rather than shaming or attacking businesses, is an important tactic for them. Therefore, results suggest positive messages (i.e. benefits) rather than fear messages (i.e. consequences/poverty) are most useful for framing the campaign.

\section{Dedicate More Resources to Research and Incorporate a Diverse Range of Data/Information in Your Presentations}

The importance of Canadian data was one of the most frequently discussed topics during the interview phase, and surveys additionally reveal that lack of supportive data is one of the biggest barriers faced by participants. As the majority of participants noted government data (especially Statistics Canada) as their main source of data, this data source has been jeopardized by the cancellation of the mandatory long-form census. Other knowledge resources for living wage advocates were Vibrant Communities Canada and the Canadian Centre for Policy Alternatives.

As perceived by surveyed living wage advocates, the top reason for businesses implementing the living wage is having "sympathetic employer/personal characteristics." It is recognized that having access to a diversity of information and resources will facilitate the advocacy process, by providing an increased ability to appeal to a diverse range of individuals/potential living wage employers. There were no apparent sectors of an organization that respond more readily to the living wage argument: frontline staff were only slightly more receptive than human resources, followed by volunteers, executives and management. The use of empirical data to support a values-based case was noted, as 70\% of survey respondents answered that "appeal to knowledge" (rather than "appeal to emotion") is more effective in convincing employers to implement a living wage, while 4/4 interviewees indicated the use of a valuesbased approach (i.e. showing employers how workers, communities, and the company can benefit from a living wage). Based on results, empirical data supporting actualized benefits to workers, communities, society, companies, etc., may be most useful when used to support values-based arguments.

\section{Discussion}

At the micro level, the research adds to the literature by compiling best practices in implementing a living wage policy. Many poverty reduction advocates are now using the living wage strategy to combat poverty. One participant stated that their campaign's biggest strength is "[their] ability to advocate on the basis that [they] recognize there are 30,000 people going to work every day but are still in poverty. This sentiment was echoed by other interviewees who mentioned how important it was for them and their campaign team to be convinced that a living wage would benefit the community. Further, nearly half of all survey participants responded that for them, the main benefit of a living wage is increased community standards of living.

At the mezzo level, the positive outcomes of the community-based research course have

Engaged Scholar Journal: Community-Engaged Research, Teaching and Learning 
been numerous (Schwartz, 2010). Its design allows students to complete a full research project, experience the ethics review process, and comprehend CBR ideals and realities of working with community partners. Social work students in this project gained exposure to prominent organizations in their community and learned about the challenges of participating in truly inclusive research projects. Students completed the course with tangible knowledge products with potential for scholarly publication, delivered their first conference presentations to their professional associations and other research groups, and finished their coursework with the knowledge that living wage advocates have used the primary information to inform their own research and/or practice. One author made the transition to employment at Vibrant Communities. This course has not only facilitated the student learning experience, but also built résumés and introduced students to professional community networks.

At the macro level, the fact that living wage advocates used the best practices information gleaned from this research in their work in advocating for a living wage is documentation of the benefit to the community of partnering with a university.

\section{Limitations}

The most significant research limitation is the small sample size of participants. Technical difficulties with the survey software, and limited time (research was part of a required course in the MSW program) prevented the research time from recruiting more participants. The length of the survey (fifty questions) may have led to lower response rates as the literature on community-based research and community-campus engagement indicates community-based organizations (CBOs) are often very busy and low on various resources. Feedback was received from potential participants indicating that the questions were primarily aimed at more mature living wage campaigns, and were therefore not applicable to the entire population. Further limitations include (a) the potential that other non-advocacy individuals filled out the survey (offered via e-mail and shared on Vibrant Communities' Twitter feed), (b) inability of survey participants to ask clarification of questions from the research team, (c) the limited ability of the research team to follow-up with individuals to ensure completion of the survey, and (d) possible deliberately distorted data.

With regards to the community-based research course, limitations include finding the correct match between students and community organizations. While all researchers are at the Masters level, students come to the program from a wide range of background, interests, and strengths. Planning and meetings between the course instructor and community partner take place prior to the beginning of the semester; however, student characteristics are an unknown factor in the planning, and students are given very limited time and information for selecting their research projects. One reflexive journal was assigned to the class in each semester to provide insight into how the project is influenced by each individual, and attempt to overcome this bias. While student characteristics have not limited the living wage project in a visible sense, it is possible that differing political views and/or student strengths have limited student investment and research potential of the project. 


\section{Conclusion}

This has been CFICE's first trial in doing community-engaged scholarship on multiple levels, using student community service learning to complete community-based research together with project partners, facilitating community-campus engagement for poverty reduction. The student project concluded with several expected and unanticipated results. Students gained course credit and were exposed to working with community-based organizations in their field of study; students gained knowledge of community-based research; and both they and the community learned about best practices to implement a living wage. Value was also created as students took their learning outside of the classroom, presenting information to community members in a way that allowed networking and the easy dissemination of knowledge; through this process, students experienced the exchange of information between classroom and community and could see the response to their eight months of research. The community gained a trained employee, and their larger membership gained a new tool to facilitate their advocacy efforts.

Creating and managing a living wage campaign to tackle poverty reduction is a big undertaking, and advocates are still navigating the system to identify what is most successful. This study is unique as the majority of research on the living wage has been conducted in the United States. One participant specifically noted the lack of Canadian literature on the viability of the living wage as an impediment to their campaign. This information provides a good snapshot of what various groups have experienced as successful or unsuccessful strategies in varying geographical areas and situations. This study will materially contribute to the pool of knowledge on the living wage and inform advocates as they begin and continue forward with their campaigns.

\section{Acknowledgements}

This research was supported by the Social Sciences and Humanities Research Council of Canada through the Community First: Impacts of Community Engagement Project.

We would also like to acknowledge the wisdom, guidance and invaluable input from Donna Jean Forster-Gill of Vibrant Communities.

\section{About the Authors}

Following the completion of her Master of Social Work and Bachelor of Social Work degrees at Carleton University, Natasha Pei (corresponding author) is working in the community engagement field, with Tamarack Institute for Community Engagement, as a Community Animator for their poverty reduction learning community. Her background is primarily in community capacity-building through environmental initiatives and humanitarian actions in China, as well as food justice organizing in Canada. Email: natashapei@cmail.carleton.ca 
Janice Feltham is a graduate of Carleton University's Master of Social Work program. After completing her Bachelor of Social Work degree at King's University College (University of Western Ontario), she worked as a long-term care home social worker. Janice's professional interests include services, programs, and policies to improve quality of life for individuals diagnosed with dementia, caregivers, and long-term care home residents. Email: janicefeltham@cmail.carleton.ca

As a social worker in the Ottawa area, Ian Ford is interested in various areas of social justice and advocacy. Specifically, Ian has done work in the area of disability and engaging men in a conversation about violence against women. As well, Ian has worked with men in a transitional housing program and with people living with HIV/AIDS. Email: ian.ford86@gmail.com

Karen Schwartz, PhD, is Associate Dean of Research and Graduate Affairs for the faculty of Public Affairs and an associate professor at Carleton University. Her areas of practice and research involve community-engaged scholarship, field education, mental health, and social work pedagogy. She teaches a research course where students engage in community-based research and has a SSHRC grant exploring the benefits to the community from campus engagement. She has co-authored the book Research For Social Justice: A Community Based Approach. Email: Karen.Schwartz@carleton.ca

\section{References}

Born, P. (ed.). (2008). Creating Vibrant Communities. Toronto: Tamarack.

Boyce, B. (2013). Collective impact: Aligning organizational efforts for broader social change. Academy of Nutrition and Dietetics, 113(4), 495-497.

Brenner, M.D. (2005). The economic impact of the Boston Living Wage Ordinance. Industrial Relations, 44(1), 59-83.

Brenner, M.D. \& Luce, Stephanie. (2005). Living wage laws in practice: The Boston, New Haven, and Hartford experiences. report summary. Amherst, MA: Political Economy Research Institute at University of Massachusetts. Retrieved from http://umass.edu/peri/resources/livingwages. htm.

Brooks, F. (2007). The living wage movement: Potential implications for the working poor. Families in Society, 88(3), 437-442.

Cornish, M. (2012). A living wage as a buman right. Toronto: Canadian Centre for Policy Alternatives.

Flicker, S. (2008). Who benefits from community-based participatory research? A case study of the positive youth project. Health Education \& Behaviour, 35(1), 70-86.

Graces, M.L. (2011). Living wage: An introduction. Guelph: The Research Shop.

Hall, B. \& Keller, P. (2006). Towards a community-based research programme: Report of the task force on community-based research. University of Victoria, BC.

Hayes, Emily. (2006). Community service learning in Canada: A scan of the field. Retrieved from http:// www.communityservicelearning.ca

Ivanova, I. \& Klein, S. (2013). Working for a living wage: Making paid work meet basic family needs in Metro Vancouver, 2013 update. Toronto: Canadian Centre for Policy Alternatives. 
Lammam, Charles. (2014). The economic effects of living wage laws. The Fraser Institute.

Loewen, G. (2008). Collaborating with business for social transformation. Toronto: Tamarack - An Institute for Community Engagement.

MacKinnon, S. (2008). Poverty and social exclusion: Solving complex issues through comprehensive approaches. Winnipeg: Canadian Centre for Policy Alternatives.

McCarthy, M. F. (2012). Simon Fraser University: Becoming the first living wage university. Vancouver: First Call: BC Child and Youth Advocacy Coalition.

McDonald, M.A. (2007). Practicing community-engaged research. Duke University Medical Center Research Ethics. Retrived from http://researchethics.nc.duke.edu.

Niedt, Christopher, Ruiters, G., Wise, D. \& Schoenberger, E. (1999). The effects of the living wage in Baltimore, Economic Policy Institute.

Schwartz, K. (2010). Community-engaged research: Student and community perspectives. Partnerships: A Journal of Service Learning and Civic Engagement, 1(2), 1-16.

Seifer, S.D. (2006). Building and sustaining community-institutional partnerships for prevention research: Findings from a national collaborative. Corporate author: Examining CommunityInstitutional Partnerships for Prevention Research Group. Journal of Urban Health, 83(6), 9891003.

Stevenson, P. (2010). A critical examination of living wage law: Case in point, Baltimore, Maryland. University of Wisconsin Oshkosh/University of Wisconsin Green Bay (Assignment for Social Work 728: Advanced Social Welfare Policy Analysis). Retrieved from https://www.uwgb.edu/ socwork/files/pdf/living_wage_policies_stevenson_2010.pdf

Stewart, S. (2013). United way, healthy communities, and collective impact. National Civic Review, 102, 75-78.

van de Sande, A., \& Schwartz, K. (2011). Research for social justice: A community-based perspective. Fernwood Press: Halifax, Nova Scotia.

White, R. G. (2012). Corporate social responsibility and a living wage. Toronto: Canadian Centre for Policy Alternatives. 